\title{
The spatial distribution and sedimentary processes of organic matter in surface sediments of Nam Co, Central Tibetan Plateau
}

\author{
WANG Yong ${ }^{1,3}$, ZHU LiPing $^{1 *}$, WANG JunBo ${ }^{1}$, JU JianTing $^{1} \&$ LIN Xiao $^{2}$ \\ ${ }^{1}$ Key Laboratory of Tibetan Environmental Changes and Land Surface Processes, Institute of Tibetan Plateau Research, Chinese Academy of \\ Sciences, Beijing 100101, China; \\ ${ }^{2}$ Key Laboratory of Biogeology and Environmental Geology of Ministry of Education, China University of Geosciences, Wuhan 430074, China; \\ ${ }^{3}$ Graduate University of the Chinese Academy of Sciences, Beijing 100049, China
}

Received June 7, 2012; accepted July 20, 2012

\begin{abstract}
In this study, 67 surface sediment samples collected from Nam Co in central Tibet were analyzed for total carbon, total organic carbon and total nitrogen, and 51 of these samples were also analyzed for $n$-alkanes. The origin and spatial distribution of organic matter were then investigated using these proxies, and the control factors responsible for the spatial distribution patterns and paleolimnological significance were discussed. The results indicated that the origin of organic matter in surface sediment of Nam Co is consistent with the sources of $n$-alkanes, which were primarily submerged plants, followed by terrestrial plants, and then aquatic algae and bacteria. The organic matter in surface sediments of the lake showed typical spatial variability. Because of the great influence of underwater topography, river inputs and water quality, the spatial distribution of organic matter is enriched from the source to the deposit center. This spatial variability of organic matter in the lake indicates that the sediments in different areas have different sensitivities to environmental changes, which is important to reconstruction of paleoenvironments and paleoclimate using lake sediment cores.
\end{abstract}

Tibetan Plateau, Nam Co, surface sediments, spatial distribution, sedimentary processes

Citation: Wang Y, Zhu L P, Wang J B, et al. The spatial distribution and sedimentary processes of organic matter in surface sediments of Nam Co, Central Tibetan Plateau. Chin Sci Bull, 2012, 57: 4753-4764, doi: 10.1007/s11434-012-5500-9

Lake sediments are widely utilized for reconstruction of climatic and environmental changes because they possess continuous depositional sequences and rich proxies with apparent environmental significance [1]. In addition to accurate dating, correct understandings of proxies are essential to reasonable explanations of the facts and mechanisms involved with environmental changes [2,3]. Lake sediments have experienced transportation, deposition or re-deposition since originating from their source areas, and then been permanently deposited in the lake bottom, where the proxies might imply different environmental conditions. In some small lakes, the proxies may have very simple explanations, because they consist of simple sedimentary processes [4], but these environmental conditions might only have local

*Corresponding author (email: lpzhu@itpcas.ac.cn) representations. Proxies from large lakes are indicators of the regional environment, but development of proper understanding and explanation of these factors is always difficult because large lakes have complicated sedimentary processes [5].

With the development of global change studies, the role of the Tibetan Plateau has generated increased interest owing to its key position and unique features [6]. Accordingly, lake sediments are being widely and thoroughly studied in this area, because there are more than 1000 lakes with areas greater than $1 \mathrm{~km}^{2}$ present on the plateau [7]. Although these lakes provide many natural environmental archives for past environmental changes [8-14], the explanations of the proxies are still based on lake studies of the lowland or other areas. However, for lakes with complicated sedimentary environments, especially large lakes, it is essential to under- 
stand the spatial distribution and enrichment conditions of sediments when reconstructing the paleoclimate and paleoenvironment $[15,16]$. Moreover, single core sediments should be tested to determine if environmental changes in the lake basin are representative of the region [17]. Therefore, it is necessary to understand the modern sedimentary processes of lakes to clarify the environmental significance of proxies [18]. Because surface sediments contain information regarding the formation, sedimentation and distribution of sediments within a lake [19-22], in this study, we used the organic matter indices of 67 surface sediments from Nam Co, the second largest lake on the Tibetan Plateau, to elucidate the spatial distribution of sediments and their sedimentary processes. This study will provide evidence for interpretation of long sediment records within the lake.

\section{Study site}

Nam Co $\left(30^{\circ} 30^{\prime}-30^{\circ} 55^{\prime} \mathrm{N}, 90^{\circ} 16^{\prime}-91^{\circ} 03^{\prime} \mathrm{E}\right)$ is located on the central part of the Tibetan Plateau at an elevation of about $4718 \mathrm{~m}$ with a catchment area of $1.061 \times 10^{4} \mathrm{~km}^{2}$. The lake is approximately $78 \mathrm{~km}$ long and the maximum width of about $44 \mathrm{~km}$ is in the western part of the lake [23] (Figure 1(a)). The landform of the lake basin and bathymetric
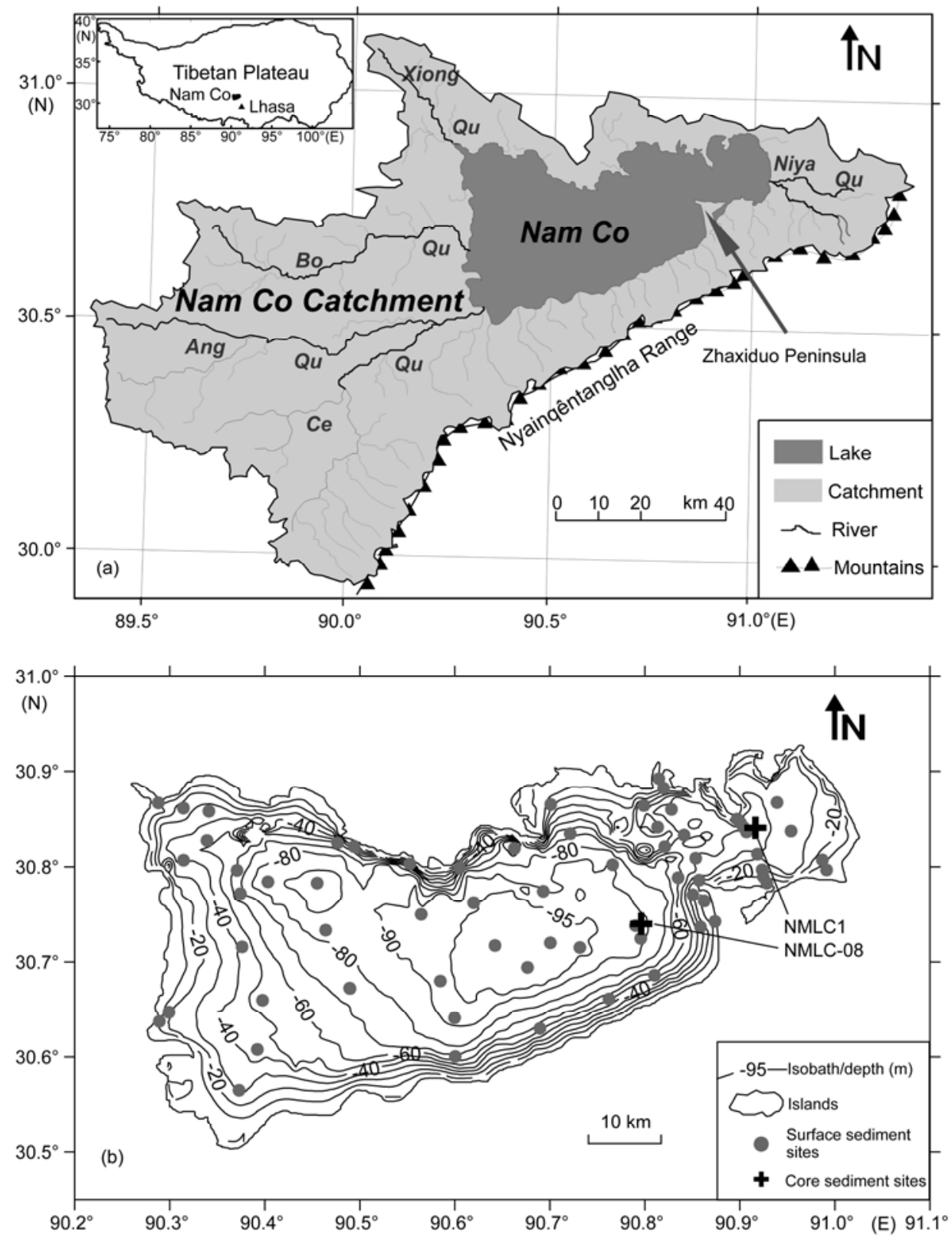

Figure 1 Map of the Nam Co Catchment (a) and bathymetric map of Nam Co and sediment sampling sites (b). 
survey show that it is a closed deep lake with a water depth greater than $90 \mathrm{~m}$ in nearly $50 \%$ of the lake area [14]. The lake is composed of a large central basin and small eastern basin separated by the Zhaxiduo Peninsula and two small islands located in the eastern part of the lake. The large central basin is the main basin of the lake, encompassing more than $80 \%$ of the entire lake and having a maximum water depth greater than $95 \mathrm{~m}$. The maximum water depth of the small eastern basin is about $65 \mathrm{~m}$, and its area accounts for less than $20 \%$ of the entire basin. The main basin of the lake has a flat bottom, but steep slopes on the southern and northern shore areas, which show typical tectonic lake features that may indicate the existing of faults (Figure 1(b)). Because of the main inflow of river water occurring in the eastern and western parts of the lake and the transportation of high volumes of sediments into the lake it possesses gentle slopes with some alluvial fans [23].

Climatically, the catchment belongs to a semi-arid and semi-humid continental climate zone. The mean annual precipitation in the area of the lake is $\sim 281 \mathrm{~mm}$ and the annual evaporation from the lake surface is $790 \mathrm{~mm}$ [24]. The vegetation in the catchment is primarily composed of alpine meadow, alpine steppe and alpine shrubbery. The aquatic plants belong to the hydrophyte subregion of the inland water system in the Southern Qiangtang Plateau [25]. The plants are dominated by submerged species, and only a few floating-leaved plants are present. The dominant aquatic plant species are Cyperaceae, Ranunculaceae, Potamogetonaceae and Haloragaceae [26].

More than 60 rivers flow into the lake during summer. Several large perennial rivers, including the Bo, Ang, Ce and Niya, are distributed in the eastern and western part of the lake (Figure 1(a)). These rivers are mainly supplied by precipitation, snow meltwater and glacial meltwater, and finally flow into the lake after passing through the wide alpine steppe/meadow area. The small rivers are primarily distributed in the southern part of the lake and are mainly supplied by meltwater from modern glaciers on the Nyainqêntanglha Range on the southeast margin of the lake catchment. Most of these rivers flow only a very short distance from the source to the lake and have a low river discharge. During 1971-2004, the lake water area increased from $1920 \mathrm{~km}^{2}$ [27] to $2015 \mathrm{~km}^{2}$ [28] owing to increased melting of glacial water supplies of the lake catchment.

\section{Material and methods}

\subsection{Surface sediment sampling}

During August 2007 and 2008, a total of 67 surface sediment samples were collected from representative sites all over the lake basin (Figure 1(b)) using an Ekman style stainless steel grab sampler. The depth of the sampling sites varied from 11 to $98 \mathrm{~m}$ and the samples were cube shaped with dimensions of $20 \mathrm{~cm} \times 30 \mathrm{~cm} \times 8 \mathrm{~cm}$. Some of the top
0.5-1 cm sediment samples were disturbed during grab sampling; however, the overall sediment samples kept their original depositional sequence because their cubic shape was not changed. Because the modern sedimentation rate of Nam Co ranges from 0.043 to $0.227 \mathrm{~cm} / \mathrm{a}$ [29] and long core sediments collected in the Tibetan Plateau are known to cover about 50 years, the top $3 \mathrm{~cm}$ of surface sediment (13-70 years) were collected, placed into pre-cleaned 100 $\mathrm{mL}$ glass bottles and capped to guarantee the $n$-alkane analysis. All collected samples were transported to the laboratory and kept frozen for further processing.

\subsection{Analysis of TOC and TN}

All samples were freeze-dried and then ground to be able to pass through a size 80 mesh. Total carbon (TC), total organic carbon (TOC) and total nitrogen $(\mathrm{TN})$ concentrations were measured using a Vario EL II Elemental Analyzer (Elementar Analysensysteme GmbH, Germany). The relative error was found to be less than $1 \%$ according to repeated testing of a standard sample. Specific experimental methods are provided elsewhere [30].

\section{$2.3 n$-Alkane separation and analysis}

Due to some sample weights being too low or containing a great deal of coarse sand, only 51 of the total 67 collected samples were used for analysis of $n$-alkanes. The water depth of these surface sediments ranged from 11 to $97.5 \mathrm{~m}$, and the average depth was $57 \mathrm{~m}$.

About $10 \mathrm{~g}$ of freeze-dried sediment sample was finely ground and extracted with solvent (dichloromethane and methanol, $V: V=10: 1$ ) for $72 \mathrm{~h}$ using the Soxhlet extraction method. Pure copper chips were added into the extracted solution to trap any sulfur. After the samples were extracted, the extract was concentrated to $5-10 \mathrm{~mL}$ by evaporation under a highly pure nitrogen stream and then fractionated by silica gel column chromatography $(2.5 \mathrm{~cm}$ inner diameter, ca. $25 \mathrm{~cm}^{3}$ activated silica gel) and eluted with hexane $(80 \mathrm{~mL})$, chloroform $(60 \mathrm{~mL})$ and methanol $(60 \mathrm{~mL})$ for $n$-alkanes, aromatic hydrocarbons and polar molecules, respectively. The volume of $n$-alkane solution was kept at $200 \mu \mathrm{L}$ before being measured by gas chromatography and mass spectrometry. The blank samples were run under similar conditions and no $n$-alkanes were detected. GC-MS analysis was conducted using Thermo Finnigan Trace GC Ultra \& Polaris Q MS interfaced directly with a DB-5MS silica capillary column (30 m length, $0.25 \mathrm{~mm}$ bore, $0.25 \mu \mathrm{m}$ film thickness). The analysis procedure consisted of heating the column from 110 to $320^{\circ} \mathrm{C}$ at a rate of $6^{\circ} \mathrm{C} / \mathrm{min}$. The temperature of the ion source and intersection was 250 and $300^{\circ} \mathrm{C}$, respectively, and gaseous helium was applied at 1.0 $\mathrm{mL} / \mathrm{min}$. n-Alkanes with different carbon chain lengths were determined by their retention time and characteristic ion debris, and their concentrations were calculated using a 
standard curve of $n-\mathrm{C}_{14-35}$ alkanes.

\section{Results}

The TOC concentrations of the surface sediments ranged from $0.19 \%$ to $2.14 \%$, with a mean value of $1.09 \%$ (Table $1)$. There were also distinct spatial distribution characteristics. In general, higher TOC concentrations were located in the eastern small basin and the northwestern and western part of the large basin near the river mouth, while lower TOC concentrations were observed in the southern and

Table 1 TOC, TN concentrations and $\mathrm{C} / \mathrm{N}$ ratio in surface sediments of Nam Co

\begin{tabular}{|c|c|c|c|c|c|c|}
\hline Sample & Longitude $\left({ }^{\circ} \mathrm{E}\right)$ & Latitude $\left({ }^{\circ} \mathrm{N}\right)$ & Water depth (m) & TOC $(\%)$ & $\mathrm{TN}(\%)$ & $\mathrm{C} / \mathrm{N}$ \\
\hline NMSS08-1 & 90.99 & 30.79 & 22 & 2.14 & 0.37 & 5.84 \\
\hline NMSS08-2 & 90.98 & 30.80 & 27 & 0.87 & 0.16 & 5.51 \\
\hline NMSS08-3 & 90.95 & 30.83 & 37 & 1.77 & 0.32 & 5.53 \\
\hline NMSS08-4 & 90.93 & 30.86 & 37 & 1.97 & 0.35 & 5.61 \\
\hline NMSS08-5 & 90.81 & 30.68 & 55 & 0.59 & 0.1 & 5.88 \\
\hline NMSS08-6 & 90.79 & 30.72 & 92 & 1.09 & 0.19 & 5.84 \\
\hline NMSS08-7 & 90.79 & 30.73 & 94 & 1.13 & 0.2 & 5.71 \\
\hline NMSS08-8 & 90.76 & 30.80 & 91 & 1.09 & 0.19 & 5.67 \\
\hline NMSS08-9 & 90.73 & 30.71 & 96 & 1.16 & 0.2 & 5.84 \\
\hline NMSS08-10 & 90.67 & 30.69 & 98 & 1.16 & 0.21 & 5.66 \\
\hline NMSS08-11 & 90.64 & 30.71 & 97 & 1.21 & 0.22 & 5.58 \\
\hline NMSS08-13 & 90.60 & 30.79 & 60 & 0.92 & 0.17 & 5.25 \\
\hline NMSS08-14 & 90.66 & 30.81 & 87 & 1.38 & 0.26 & 5.34 \\
\hline NMSS08-15 & 90.69 & 30.77 & 95 & 1.22 & 0.22 & 5.58 \\
\hline NMSS08-16 & 90.76 & 30.66 & 54 & 0.59 & 0.11 & 5.33 \\
\hline NMSS08-17 & 90.68 & 30.62 & 55 & 0.61 & 0.13 & 4.71 \\
\hline NMSS08-18 & 90.70 & 30.72 & 97 & 1.19 & 0.22 & 5.48 \\
\hline NMSS08-19 & 90.72 & 30.83 & 68 & 1.17 & 0.21 & 5.51 \\
\hline NMSS08-20 & 90.70 & 30.86 & 32 & 0.46 & 0.1 & 4.53 \\
\hline NMSS08-21 & 90.79 & 30.86 & 31 & 0.38 & 0.08 & 4.78 \\
\hline NMSS08-22 & 90.81 & 30.84 & 45 & 0.19 & 0.05 & 3.65 \\
\hline NMSS08-23 & 90.82 & 30.82 & 45 & 0.74 & 0.14 & 5.25 \\
\hline NMSS08-25 & 90.85 & 30.77 & 32 & 0.68 & 0.12 & 5.48 \\
\hline NMSS08-26 & 90.85 & 30.78 & 35 & 0.99 & 0.16 & 6.37 \\
\hline NMSS08-27 & 90.85 & 30.80 & 48 & 0.81 & 0.15 & 5.36 \\
\hline NMSS08-28 & 90.84 & 30.83 & 60 & 1.11 & 0.19 & 5.83 \\
\hline NMSS08-29 & 90.82 & 30.85 & 54 & 1.4 & 0.24 & 5.78 \\
\hline NMSS08-30 & 90.81 & 30.88 & 40 & 1.27 & 0.22 & 5.91 \\
\hline NMSS08-31 & 90.81 & 30.89 & 25 & 0.88 & 0.19 & 4.69 \\
\hline NMSS08-32 & 90.89 & 30.84 & 20 & 0.51 & 0.1 & 5.02 \\
\hline NMSS08-33 & 90.90 & 30.84 & 47 & 0.53 & 0.1 & 5.06 \\
\hline NMSS08-34 & 90.90 & 30.84 & 60 & 1.77 & 0.31 & 5.7 \\
\hline NMSS08-35 & 90.90 & 30.83 & 51 & 1.78 & 0.31 & 5.77 \\
\hline NMSS08-36 & 90.91 & 30.81 & 40 & 1.55 & 0.28 & 5.6 \\
\hline NMSS08-37 & 90.92 & 30.79 & 30 & 0.37 & 0.1 & 3.82 \\
\hline
\end{tabular}


(Continued)

\begin{tabular}{|c|c|c|c|c|c|c|}
\hline Sample & Longitude $\left({ }^{\circ} \mathrm{E}\right)$ & Latitude $\left({ }^{\circ} \mathrm{N}\right)$ & Water depth (m) & TOC $(\%)$ & $\mathrm{TN}(\%)$ & $\mathrm{C} / \mathrm{N}$ \\
\hline NMSS08-38 & 90.92 & 30.78 & 21 & 1.81 & 0.41 & 4.38 \\
\hline NMSS08-39 & 90.92 & 30.78 & 16 & 1.19 & 0.19 & 6.23 \\
\hline NMSS08-40 & 90.86 & 30.76 & 12 & 0.32 & 0.08 & 4.07 \\
\hline NMSS08-41 & 90.87 & 30.74 & 7 & 0.1 & 0.04 & 2.56 \\
\hline NMSS08-42 & 90.85 & 30.73 & 34 & 0.81 & 0.16 & 5.08 \\
\hline NMSS07-1 & 90.31 & 30.80 & 40 & 1.39 & 0.21 & 6.53 \\
\hline NMSS07-2 & 90.33 & 30.82 & 47 & 1.22 & 0.19 & 6.25 \\
\hline NMSS07-3 & 90.37 & 30.79 & 63 & 1.3 & 0.2 & 6.47 \\
\hline NMSS07-4 & 90.37 & 30.77 & 68 & 1.28 & 0.19 & 6.8 \\
\hline NMSS07-5 & 90.40 & 30.78 & 89 & 1.25 & 0.19 & 6.44 \\
\hline NMSS07-6 & 90.49 & 30.82 & 59 & 1.18 & 0.17 & 7 \\
\hline NMSS07-7 & 90.47 & 30.82 & 61 & 1.2 & 0.17 & 6.87 \\
\hline NMSS07-8 & 90.45 & 30.78 & 92 & 1.29 & 0.22 & 5.99 \\
\hline NMSS07-9 & 90.46 & 30.73 & 84 & 1.23 & 0.19 & 6.53 \\
\hline NMSS07-10 & 90.48 & 30.67 & 75 & 1.1 & 0.17 & 6.43 \\
\hline NMSS07-11 & 90.48 & 30.67 & 75 & 1.16 & 0.17 & 6.98 \\
\hline NMSS07-12 & 90.56 & 30.75 & 93 & 1.29 & 0.2 & 6.49 \\
\hline NMSS07-13 & 90.55 & 30.80 & 45 & 0.3 & 0.07 & 4.53 \\
\hline NMSS07-14 & 90.58 & 30.67 & 94 & 1.14 & 0.19 & 5.89 \\
\hline NMSS07-15 & 90.59 & 30.64 & 92 & 1.05 & 0.18 & 5.73 \\
\hline NMSS07-16 & 90.60 & 30.60 & 70 & 0.89 & 0.15 & 5.99 \\
\hline NMSS07-17 & 90.37 & 30.71 & 44 & 1.16 & 0.2 & 5.82 \\
\hline NMSS07-18 & 90.29 & 30.64 & 20 & 1.04 & 0.18 & 5.74 \\
\hline NMSS07-19 & 90.28 & 30.63 & 11 & 1.93 & 0.3 & 6.37 \\
\hline NMSS07-20 & 90.39 & 30.65 & 55 & 1.08 & 0.19 & 5.7 \\
\hline NMSS07-21 & 90.39 & 30.60 & 45 & 0.64 & 0.11 & 5.77 \\
\hline NMSS07-22 & 90.37 & 30.56 & 31 & 0.28 & 0.06 & 4.76 \\
\hline NMSS07-23 & 90.28 & 30.86 & 15 & 2.26 & 0.37 & 6.19 \\
\hline NMSS07-24 & 90.31 & 30.86 & 25 & 0.93 & 0.18 & 5.26 \\
\hline NMSS07-25 & 90.34 & 30.85 & 35 & 1.03 & 0.19 & 5.54 \\
\hline Average & & & 54 & 1.07 & 0.19 & 5.57 \\
\hline
\end{tabular}

northern littoral zones (Figure 2(a)). In the large central basin, TOC concentrations changed with isobaths and showed characteristics of concentric circles to a certain degree, demonstrating that the values in deep areas were higher than in shallow areas (Figure 2(a)). Although the values were calculated from the annual sedimentation flux, the TOC still had spatial distribution characteristics similar to those mentioned above because of the higher sedimentation rates in deeper areas.

$\mathrm{TN}$ concentrations of surface sediments were much lower than those of the TOC, ranging from $0.04 \%$ to $0.41 \%$ with a mean value of $0.19 \%$ (Table 1). These findings were well correlated with the TOC concentration (Table 2) and showed similar spatial distributions. However, the area with high
TN concentrations was much smaller than the area with high TOC levels, despite their having the same concentric circle distribution (Figure 2(b)).

Surface sediments showed $\mathrm{C} / \mathrm{N}$ ratios between 2.6 and 7.0 with an average value of 5.57. The spatial distribution of the $\mathrm{C} / \mathrm{N}$ ratio was not the same as that of the TOC and TN. Rather, the $\mathrm{C} / \mathrm{N}$ ratios remained relatively stable in the eastern small basin and were high throughout the western basin, except in the southwest corner (Figure 2(c)).

The $n$-alkane homologues of surface sediments were detected well using GC-MS and ranged from $\mathrm{C}_{14}$ to $\mathrm{C}_{35}$. All samples had strong odd to even carbon number predominance after $\mathrm{C}_{20}$ and no obvious predominance for this characteristic before $\mathrm{C}_{20}$, with the most abundant carbon numbers 

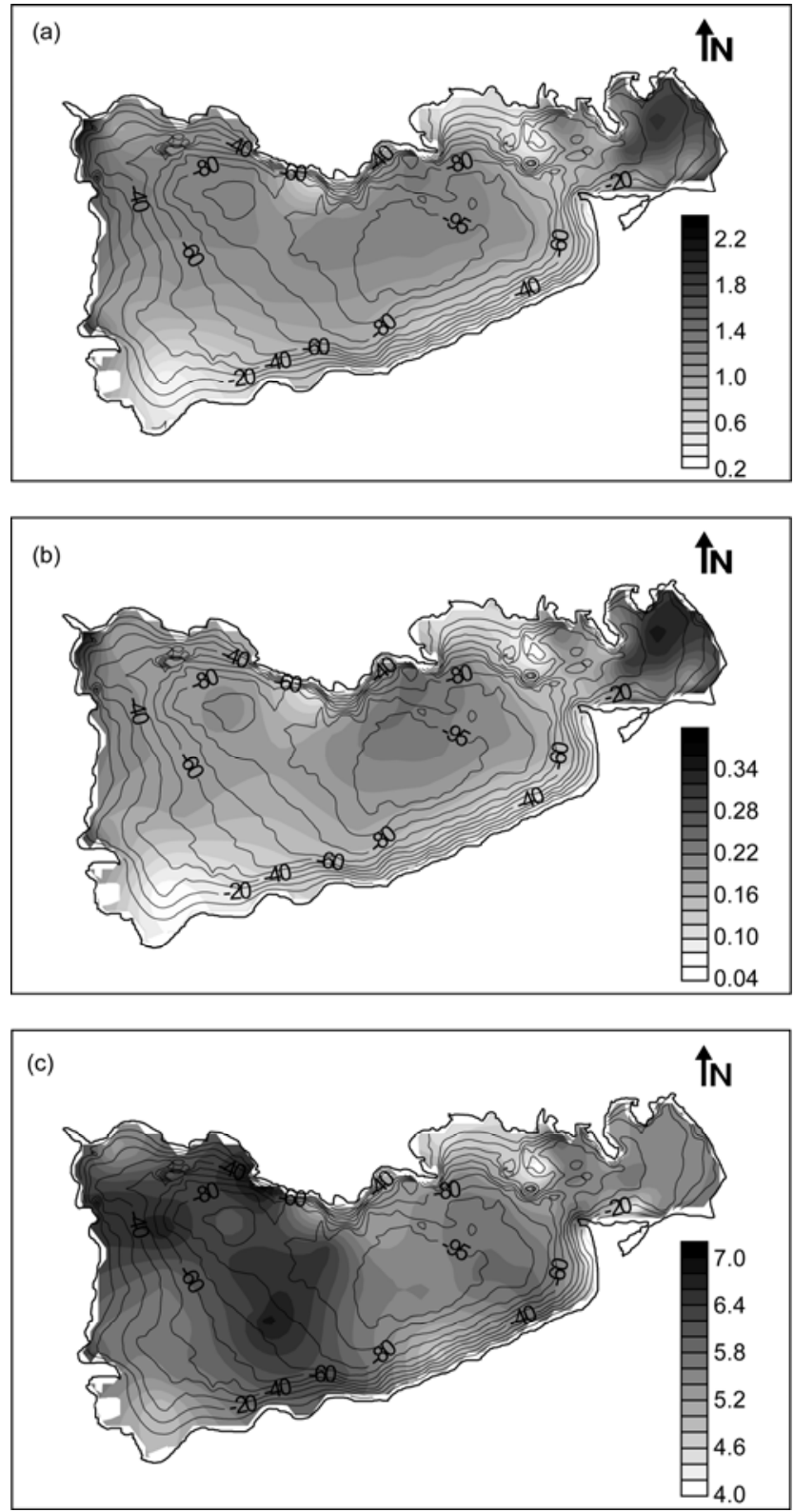

Figure 2 Interpolated spatial distribution maps showing the concentrations of TOC (a), TN (b) and C/N (c) in surface sediments of Nam Co (\%). being $\mathrm{C}_{27}, \mathrm{C}_{29}$ and $\mathrm{C}_{31}$. By analyzing the distribution characteristics of all surface sediment samples, the $n$-alkane distribution patterns could be divided into three models (Figure 3): (1) Mode I, bimodal distribution with the maxima at $\mathrm{C}_{31}$ and relatively high $\mathrm{C}_{23}$, most samples showed this distribution pattern; (2) Mode II, bimodal distribution with the maxima at $\mathrm{C}_{23}$ and relatively high $\mathrm{C}_{31}$, only found in samples 08-2, 08-39 and 07-19; and (3) Mode III, trimodal distribution with the maxima at $\mathrm{C}_{31}$ and relatively high $\mathrm{C}_{17}$ and $\mathrm{C}_{23}$, only found in sample $08-1$.

\section{Discussion}

\subsection{The spatial distribution and influence factors of TOC, TN and C/N}

TOC concentration is a fundamental proxy for describing the abundance of organic matter in sediments that is mainly influenced by the endogenous (aquatic organisms) and exogenous (terrestrial vegetation) organic matter input. The TOC can represent lake productivity when it primarily originates from endogenous input, otherwise it will indicate the productivity and input ability of terrestrial vegetation because of its exogenous input. The average TOC concentration in surface sediments of the lake is only $1.07 \%$, which is consistent with other lakes in the Tibetan Plateau, suggesting that high altitude lakes have low lake productivity or weak terrestrial vegetation development [31]. TN in lake sediments can indicate a lake's nutritional level, and is closely related to the plankton productivity of a lake. The average TN concentration is only $0.19 \%$, indicating that the lake is oligotrophic.

Based on Kriging interpolation, the interpolated TOC and TN concentrations of surface sediments have very similar spatial distribution characteristics (Figure 2(a),(b)). This indicates that the TOC distribution is controlled by TN distribution, because TN represents the lake nutritional level, which is independent from the organic matter status [32,33]. The TN concentrations change from high to low with distance to the river mouth in the northwestern part of the large

Table 2 Correlation matrix of water depth and all proxies in surface sediments of Nam Co

\begin{tabular}{|c|c|c|c|c|c|c|c|c|}
\hline & Water depth & TOC & $\mathrm{TN}$ & $\mathrm{C} / \mathrm{N}$ & Total $n$-alkanes & $n-\mathrm{C}_{27}+\mathrm{C}_{29}+\mathrm{C}_{31}+\mathrm{C}_{33}$ & $n-\mathrm{C}_{21}+\mathrm{C}_{23}+\mathrm{C}_{25}$ & $n-\mathrm{C}_{15}+\mathrm{C}_{17}+\mathrm{C}_{19}$ \\
\hline Water depth & 1.00 & & & & & & & \\
\hline TOC & 0.06 & 1.00 & & & & & & \\
\hline $\mathrm{TN}$ & 0.04 & 0.97 & 1.00 & & & & & \\
\hline $\mathrm{C} / \mathrm{N}$ & 0.23 & 0.51 & 0.31 & 1.00 & & & & \\
\hline Total $n$-alkanes & 0.04 & 0.90 & 0.87 & 0.44 & 1.00 & & & \\
\hline$n-\mathrm{C}_{27}+\mathrm{C}_{29}+\mathrm{C}_{31}+\mathrm{C}_{33}$ & 0.11 & 0.79 & 0.79 & 0.31 & 0.92 & 1.00 & & \\
\hline$n-\mathrm{C}_{21}+\mathrm{C}_{23}+\mathrm{C}_{25}$ & -0.06 & 0.87 & 0.87 & 0.36 & 0.95 & 0.89 & 1.00 & \\
\hline$n-\mathrm{C}_{15}+\mathrm{C}_{17}+\mathrm{C}_{19}$ & -0.18 & 0.66 & 0.62 & 0.30 & 0.67 & 0.41 & 0.59 & 1.00 \\
\hline
\end{tabular}




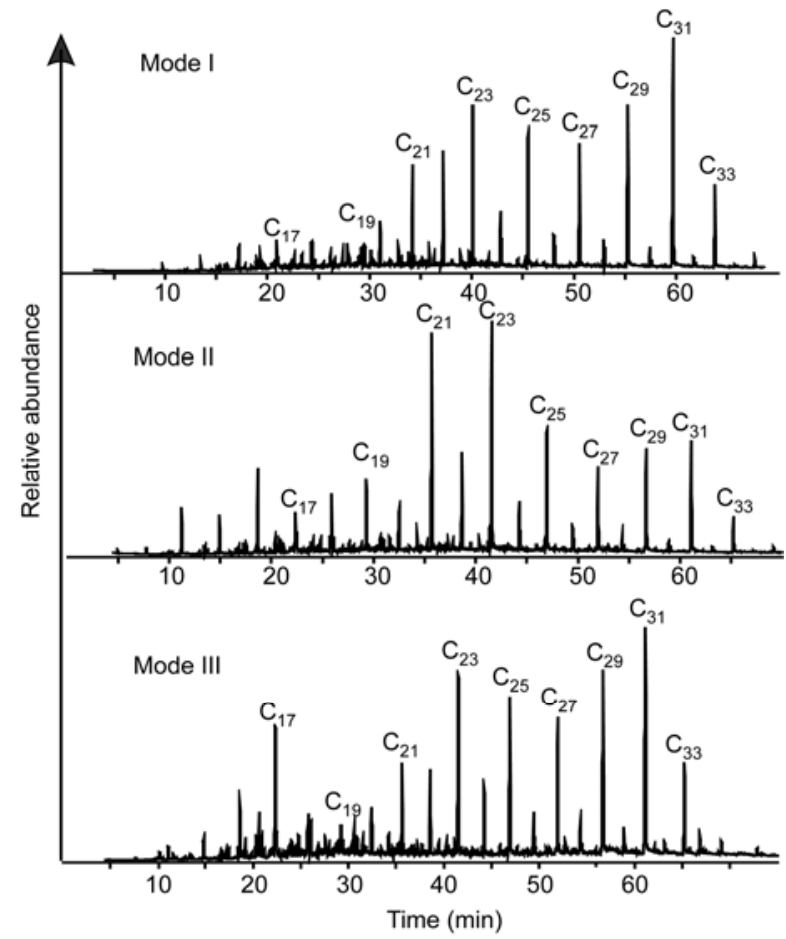

Figure 3 Typical mass chromatograms of $n$-alkanes $(m / z=85)$ of surface sediments in Nam Co.

central basin, and from the littoral to the profound zone in the small eastern basin, confirming that lake nutrients enter the system via inflow water. In the large central basin, there was a similar concentric circle spatial distribution of TOC and TN concentration, with higher values occurring with increased water depth. Deep water is not suitable for the reproduction of planktonic and benthic organisms; therefore, increasing TN concentrations may indicate that the enrichment processes occur from shallow areas to the deep deposit center. The centers of the TOC and TN concentric circles are closer to the northern region of the lake basin than the center of the isobaths, suggesting that unfavorable conditions for TN inputs and TOC occurred and accumulated in the southern part of the lake. These findings are consistent with the fact that, although there are many small rivers supplied by cold glacial meltwater flowing through the piedmont Gobi area, not many nutrients are transported to and accumulated in the southern part of the lake.

The $\mathrm{C} / \mathrm{N}$ ratio is generally used to characterize organic matter sources in lacustrine environments. When sedimentary organic matter primarily originates from endogenous materials, it has $\mathrm{C} / \mathrm{N}$ ratios between 4 and 10 because of aquatic protein-rich and cellulous-poor organisms, while it usually has $\mathrm{C} / \mathrm{N}$ ratios greater than 20 when it originates from exogenous material owing to the protein-poor and cellulous-rich nature of terrestrial plants [34,35]. However, for some shallow lakes, sedimentary organic matter may degrade due to strong oxidation or inorganic nitrogen influencing the results when the TOC concentration is less than
$0.3 \%$ [36]; accordingly, simply using the $\mathrm{C} / \mathrm{N}$ ratio to estimate the endogenous/exogenous sources of sedimentary organic matter may cause bias or incorrect conclusions. In Nam Co, the average water depth is very deep and the water temperature is low, so the oxidation and degradation of sedimentary organic matter is easily inhibited. Moreover, the TOC concentration of most samples was higher than $0.3 \%$; therefore, the effects of inorganic nitrogen are negligible. Based on these characteristics, it is suitable to use the $\mathrm{C} / \mathrm{N}$ ratio to estimate the endogenous/exogenous sources of sedimentary organic matter in Nam Co. However, since sediment TN primarily originates from exogenous input and is present in relatively low concentrations, it is not likely that it will form the same spatial distribution of plankton productivity in very low water temperature environments. Therefore, the $\mathrm{C} / \mathrm{N}$ ratio in different areas of Nam Co may have varying degrees of usefulness for estimation of the sources of sedimentary organic matter. The spatial distribution of the $\mathrm{C} / \mathrm{N}$ ratio did not show characteristics of concentric cycles such as TOC and TN, reflecting the difference in organic matter in different areas of the lake. Owing to the stable $\mathrm{C} / \mathrm{N}$ ratios in the eastern small basin, which indicate mainly exogenous inputs of TOC and TN, the low $\mathrm{C} / \mathrm{N}$ ratios may not be representative of endogenous organic matter sources. In the large central basin, the concentric circles of TN were smaller than those of TOC, indicating an uneven distribution of $\mathrm{C} / \mathrm{N}$ ratios. In the large central basin, the high $\mathrm{C} / \mathrm{N}$ ratios appeared in the southeast corner and a large band was present in the west part of the lake. However, the TOC and $\mathrm{TN}$ showed decreasing trends in those areas, indicating that the proportion of exogenous organic matter will increase in cases of very low nutritional levels in the lake.

\subsection{The spatial distribution of $\boldsymbol{n}$-alkanes}

$n$-Alkanes are one of the most commonly used biomarkers, because they provide a wealth of information related to environmental changes owing to their high resistance to alteration and degradation when compared with other types of organic matter. It is well known that $n$-alkanes with different chain-length distributions have different biological sources and content. In general, higher terrestrial plants contain long chain $n$-alkanes $\left(n-\mathrm{C}_{27}-\mathrm{C}_{33}\right)$ with odd-to-even predominance in their epicuticular waxes [37,38], whereas submerged/ floating aquatic plants contain a large proportion of midchain $n$-alkanes $\left(n-\mathrm{C}_{21}-\mathrm{C}_{25}\right)$ with odd-to-even predominance [39-41], and aquatic algae and photosynthetic bacteria contain low chain $n$-alkanes $\left(n-\mathrm{C}_{15}-\mathrm{C}_{20}\right)$ that are mainly dominated by $\mathrm{C}_{17}$ and $\mathrm{C}_{19}$ alkanes [42,43]. A previous study confirmed that long-chain $n$-alkanes $\left(n-\mathrm{C}_{27}-\mathrm{C}_{33}\right)$ originate from terrestrial plants, while mid-chain $n$-alkanes $\left(n-\mathrm{C}_{21}-\mathrm{C}_{25}\right)$ are from submerged plants and low-chain $n$-alkanes $\left(<n-\mathrm{C}_{20}\right)$ are from aquatic algae and photosynthetic bacteria [44]. Therefore, in this study, the total odd long-chain- $n$-alkanes concentration, $n-\mathrm{C}_{27}+\mathrm{C}_{29}+\mathrm{C}_{31}+\mathrm{C}_{33}$, was used as an indicator 
of terrestrial plant input to the lake, and the concentrations $n-\mathrm{C}_{21}+\mathrm{C}_{23}+\mathrm{C}_{25}$ and $n-\mathrm{C}_{15}+\mathrm{C}_{17}+\mathrm{C}_{19}$ were used to represent input from submerged plants, aquatic algae and bacterial input, respectively. The high abundance of long-chain $n$-alkanes $\left(>n-\mathrm{C}_{27}\right)$ and mid-chain $n$-alkanes $\left(n-\mathrm{C}_{21}-\mathrm{C}_{25}\right)$, as well as the low abundance of low-chain $n$-alkanes $\left(<n-\mathrm{C}_{20}\right)$ in surface sediments of Nam Co indicate that terrestrial plants and submerged plants contribute much more $n$-alkanes than aquatic algae and bacteria. Considering the correlation between $n$-alkane components and TOC and TN, the high correlation of total $n$-alkanes with TOC may indicate that the TOC and each $n$-alkane component have the same sources. The correlation coefficients between $n-\mathrm{C}_{21}+\mathrm{C}_{23}+\mathrm{C}_{25}$, $n-\mathrm{C}_{27}+\mathrm{C}_{29}+\mathrm{C}_{31}+\mathrm{C}_{33}$ and $n-\mathrm{C}_{15}+\mathrm{C}_{17}+\mathrm{C}_{19}$ and TOC were 0.87 , 0.79 and 0.66 , respectively, indicating that the contribution to TOC occurred in the following order: submerged plants> terrestrial plants $>$ aquatic algae and bacteria.

Analysis of the interpolated results of the concentration of each $n$-alkane component revealed that the total $n$-alkanes, $n-\mathrm{C}_{27}+\mathrm{C}_{29}+\mathrm{C}_{31}+\mathrm{C}_{33}$ and $n-\mathrm{C}_{21}+\mathrm{C}_{23}+\mathrm{C}_{25}$, had similar spatial distributions (Figure 4(a)-(c)). In addition to the concentric circles distribution in the deepest area of the lake with the highest concentrations, high concentrations of $n$-alkane components were also found in river mouths in the northwest and southwest portions of the large central basin. The $n$-alkane components appeared to have a saddle shaped distribution from river mouths to the center of the lake. High concentrations in the river mouths reflect terrestrial inputs, or submerged plants that are present in river deltas, while high concentrations in deep areas indicate enrichment processes in the deposit center. The high concentrations of long-chain $n$-alkanes from the river mouth to deep areas indicate that $n$-alkane components are strongly influenced by the river input and transportation. The highest concentrations of all $n$-alkane components were observed in the small eastern basin, and their spatial distribution was homogeneous with the slightly increasing trend from the shore to the center of the basin. Because of the shallower water and gentler underwater topography in the small eastern basin, sedimentary organic matter from terrestrial plants is likely rapidly transported throughout the basin with high sedimentation rates.

$n-\mathrm{C}_{15}+\mathrm{C}_{17}+\mathrm{C}_{19}$ has a uniform spatial distribution with low concentrations, although it was present in slightly higher levels in the eastern littoral zone and the river mouths in the west and southwest portions of the lake (Figure 4(d)). The correlation coefficient between $n-\mathrm{C}_{15}+\mathrm{C}_{17}+\mathrm{C}_{19}$ and $\mathrm{TN}$ was only 0.62 , indicating that the distribution of aquatic algae and bacteria is not strictly controlled by sediment nutrients. One reason for this is likely that it is difficult for TN from exogenous sources to supply nutrients to aquatic algae and bacteria quickly. Additionally, the strong waves of the lake lead to an even distribution of aquatic algae and bacteria to various areas of the lake. Thus, these findings demonstrate that simply using $\mathrm{C} / \mathrm{N}$ ratios to estimate the sources of sedimentary organic matter would lead to errors because TN cannot effectively represent the productivity of aquatic algae and bacteria in the lake.

\subsection{Influence factors and paleolimnological significance}

During permanent deposition from the source to the bottom
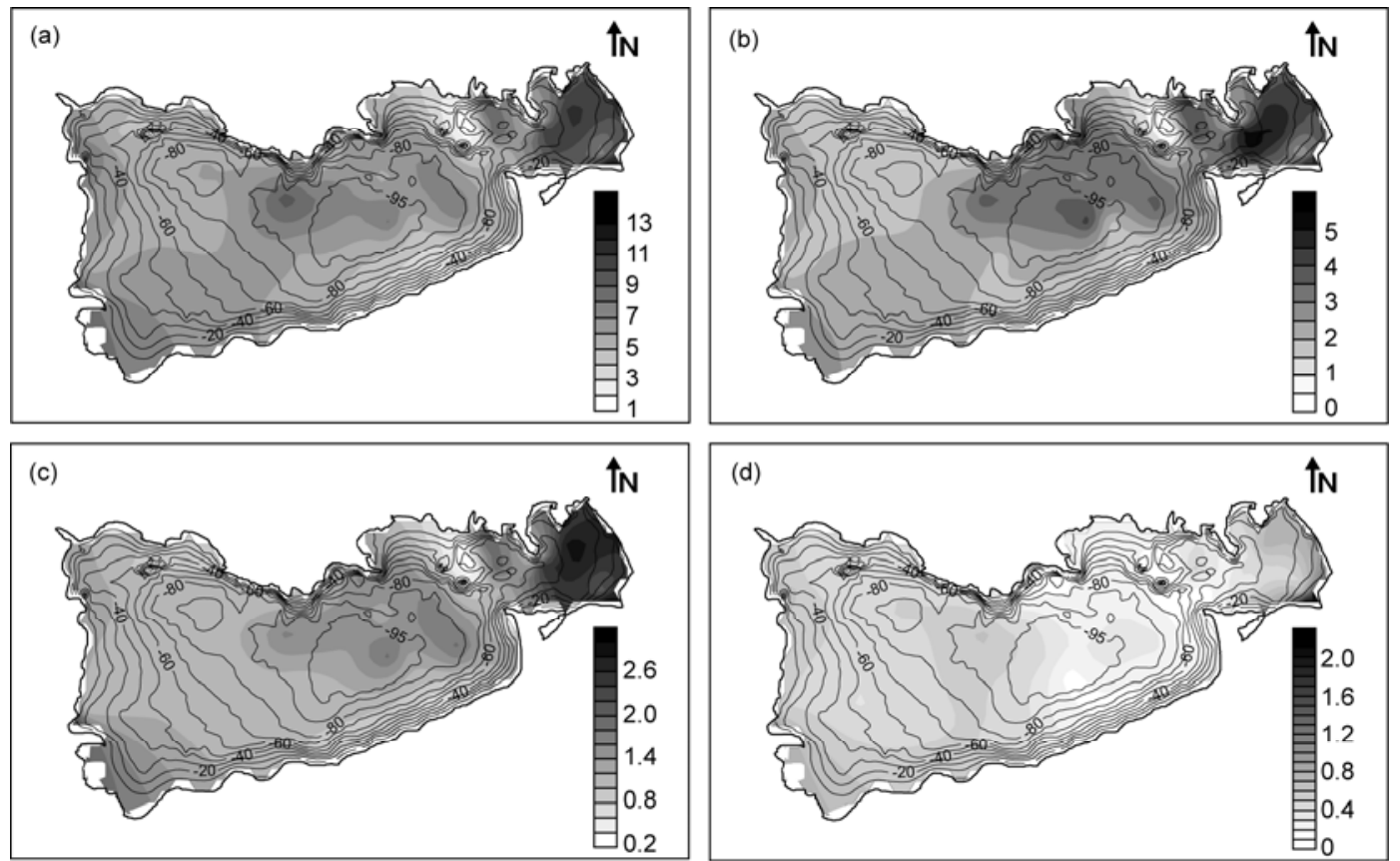

Figure 4 Interpolated spatial distribution maps showing the concentrations of total $n$-alkanes (a), $n-\mathrm{C}_{27}+\mathrm{C}_{29}+\mathrm{C}_{31}+\mathrm{C}_{33}(\mathrm{~b}), n-\mathrm{C}_{21}+\mathrm{C}_{23}+\mathrm{C}_{25}(\mathrm{c})$ and $n-\mathrm{C}_{15}+\mathrm{C}_{17}+\mathrm{C}_{19}(\mathrm{~d})$ in surface sediments of Nam Co $(\mu \mathrm{g} / \mathrm{g})$. 
of the lake, sedimentary organic matter is influenced by a variety of factors including river inputs, underwater topography, and lake wind and induced waves, which eventually leads to different spatial distribution patterns [19-23,45-47]. In some small lakes, the spatial distribution of sedimentary organic matter is relatively simple, owing to one factor showing the greatest effect [48]. However, in some large lakes, the spatial distribution is complicated owing to multifactors interacting with each other.

The supply of water by rivers plays an important role in the sources, transportation and deposition of sedimentary organic matter. Rivers primarily affect the proportion of exogenous and endogenous sedimentary organic matter by transporting terrigenous organic matter to the lake. In Nam Co, high TOC and TN concentrations were observed in the small eastern basin and river mouth areas in the northwestern part of the lake, while the concentrations gradually decreased from the river mouth to the center of the lake. These spatial distribution characteristics were closely related to river transportation. In the river mouths of the southwest and south parts of the lake, the TOC and TN concentrations were relatively low, reflecting the fact that the rivers entering those portions of the lake are strongly affected by cold glacial meltwater. The higher silt contents in these areas of the lake indicate that the supply rivers have strong hydrodynamics [49]. As a result submerged plants are limited, which results in $n$-alkanes primarily originating from terrestrial plants; therefore, they decrease in concentration from the river mouth to the center of the lake.

The underwater topography has a significant effect on sediment processes and accumulation. Analysis of the relationship between proxies of surface sediment and water depth revealed that the proxies showed very small changes at depths greater than $60 \mathrm{~m}$ (Figure 5). This depth has already been the deposit center and has flat underwater topography. In addition to $n-\mathrm{C}_{15}+\mathrm{C}_{17}+\mathrm{C}_{19}$, the other proxies analyzed were present at high concentrations in the deep area of the large central basin, especially those associated with terrestrial
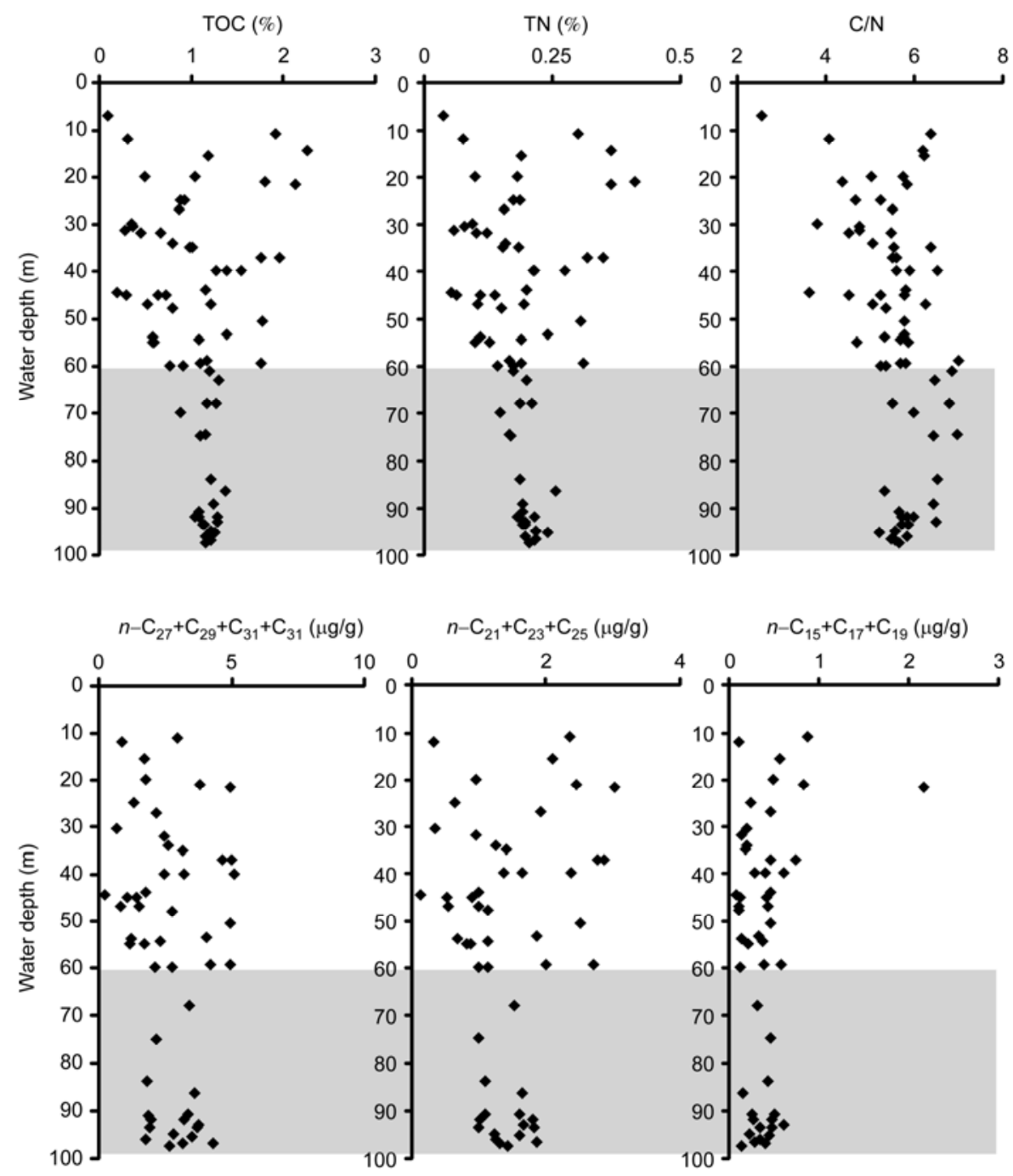

Figure 5 Relationship between organic matter proxies in surface sediments of Nam Co with water depth. 
inputs. This indicates that enrichment occurs via deposition in the center of the large lake, and that the anaerobic environment in deep areas is suitable for preservation of sedimentary organic matter. A previous study illustrated that sediment cores from the deep basins of a lake are likely to contain fine sediments that have been winnowed and resettled from shallower portions of the lake, and that all sources of organic matter would be enriched. In contrast, sediment cores from lake margins and bathymetrically elevated areas likely contain magnified information regarding terrestrial plant sources owing to the underwater topography not being suitable for submerged plant growth [21]. The lowest TOC and $\mathrm{TN}$ concentrations were in the southern and northern littoral zones. This may have been caused by the inflow river water in these areas containing low TOC and TN concentrations, but the limited submerged plant growth due to steep slopes in these areas was likely more important to these low levels. Cores in shallow areas had low sedimentation rates, primarily because few sediments accumulated on these steep slopes [29].

Lake water quality affects the sediment composition and accumulation process by influencing aquatic plant growth. The highest concentrations of all surface sediment proxies were found in the small eastern basin and river mouth areas of the northwestern part of the lake, reflecting the high organic content and nutritional levels, as well as the suitable environment for aquatic organism growth due to river input of terrigenous detritus and nutrients. The concentrations of all proxies decreased with increasing distance from the river mouth, revealing that the impact of the river on lake water quality decreased. Lake conductivity in the west was higher than that in the middle of the lake, while lake transparency showed the opposite trend [49], indicating that large rivers in the western part of the catchment transported a high volume of terrigenous detritus and minerals to the lake.

Understanding the primary factors controlling the spatial distribution of sedimentary organic matter is very important because it is fundamental to explaining environmental changes based on the composition and concentration of sedimentary organic matter. For the small eastern basin of Nam Co, the spatial distribution of organic matter in surface sediments revealed that sedimentary processes are primarily controlled by underwater topography and weakly influenced by river inputs. The increase in the concentrations of organic matter with water depth reflects the enrichment processes and higher sedimentation rates of the basin. For the large central basin, the large area and high number of inflow rivers resulted in sedimentary processes of organic matter being controlled by underwater topography, as well as river inputs. The homogeneous spatial distribution of organic matter was only observed in the deep central area, and the low concentrations of organic matter indicate low sedimentation rates in this area. Therefore, regardless of which portion of the lake is being investigated, significantly more information pertaining to paleoenvironmental change will only be captured by collecting sediment cores in the deep central area of the lake basin. Considering the different sources and sedimentation rates of organic matter in different areas of the lake, the collected sediment samples may have different sensitivities and time accuracies for paleoenvironmental reconstruction. This was reflected in two sediment cores of Nam Co. Specifically, sediment core NMLC1, which was $3.32 \mathrm{~m}$ long and collected in the small eastern basin, had a bottom age of 8.4 cal ka BP, while sediment core NMLC-08, which was $11 \mathrm{~m}$ long and collected in the large central basin, had an age of about $13 \mathrm{cal} \mathrm{ka} \mathrm{BP}$ at $3 \mathrm{~m}$.

\section{Conclusions}

In this study, the concentration, source and spatial distribution of TOC, TN and $n$-alkanes were investigated in surface sediments of Nam Co on the central Tibetan Plateau. The distribution of these proxies showed great spatial variability in the sediments. The sedimentary processes and control factors and paleoenvironmental significance were also discussed. The results presented herein provide references that can be used to explain the paleoclimate changes in Nam Co and other lakes in the Tibetan Plateau. The specific conclusions of this study are as follows:

(1) The TOC concentrations of surface sediments of the lake are relatively low and highly consistent with $n$-alkanes, and the data demonstrate that the contributions of various organisms to TOC are as follows: submerged plants>terrestrial plants $>$ aquatic algae and bacteria.

(2) The distribution of organic matter in surface sediments has typical spatial variability, reflecting different sedimentary processes and control factors. The sedimentary processes in the small eastern basin are mainly controlled by underwater topography and show generally high concentrations of organic matter and sedimentation rates. The river inputs can influence the distribution of organic matter significantly in the large central basin, although the underwater topography is still the main factor controlling sedimentary processes. The characteristics of the enrichment processes of the deposit center are all reflected in the two basins of the lake.

(3) The different concentrations, sources and sedimentation rates of organic matter between the two basins determine their sensitivity to environmental change. The organic matter in the small eastern basin is suitable for high-resolution paleoenvironmental reconstruction due to its primarily terrestrial inputs and high sedimentation rates. Conversely, the organic matter in the large central basin enables reconstruction of large-scale regional paleoenvironmental changes with long time series.

We are grateful to two anonymous reviewers for their valuable comments, which significantly improved the quality of the manuscript. This work was supported by the National Basic Research Program of China (2012- 
CB956100), the National Natural Science Foundation of China (41190082, 41071123) and the Knowledge Innovation Key Program of the Chinese Academy of Sciences (KZCX2-EW-113).

1 Dean W E. Recent advances in global lake coring hold promise for global change research in paleolimnology. J Paleolimn, 2010, 44: 741-743

2 Gilbert R, Lamoureux S. Processes affecting deposition of sediment in a small, morphologically complex lake. J Paleolimn, 2004, 31 : 37-48

3 Pienitz R, Lotter A, Newman L, et al. Advances in paleolimnology. PAGES News, 2009, 17: 92-120

4 Hilton J. A conceptual framework for predicting the occurrence of sediment focusing and sediment redistribution in small lakes. Limnol Oceanogr, 1985, 30: 1131-1143

5 Johnson T C, Kelts K, Odada E. The Holocene history of Lake Victoria. AMBIO, 2000, 29: 2-11

6 Lehmkuhl F, Owen L A. Late Quaternary glaciation of Tibet and the bordering mountains: A review. Boreas, 2005, 34: 87-100

7 Ma R H, Yang G S, Duan H T, et al. China's lakes at present: Number, area and spatial distribution. Sci China Earth Sci, 2011, 54: 283-289

8 Gasse F, Fontes J C, van Campo E, et al. Holocene environmental changes in Bangong Co basin (Western Tibet) Part 4: Discussion and conclusions. Palaeogeogr Palaeoclimatol Palaeoecol, 1996, 120: 79-92

9 Herzschuh U, Kramer A, Mischke S, et al. Quantitative climate and vegetation trends since the late glacial on the northeastern Tibetan Plateau deduced from Koucha Lake pollen spectra. Quat Res, 2009, 71: $162-171$

10 Jin Z D, Bickle M J, Chapman H J, et al. Early to mid-Pleistocene ostracod $\delta^{18} \mathrm{O}$ and $\delta^{13} \mathrm{C}$ in the central Tibetan Plateau: Implication for Indian monsoon change. Palaeogeogr Palaeoclimatol Palaeoecol, 2009, 280: 406-414

11 Kashiwaya K, Masuzawa T, Morinaga H, et al. Changes in hydrological conditions in the central Qing-Zang (Tibetan) Plateau inferred from lake bottom sediments. Earth Planet Sci Lett, 1995, 135: 31-39

12 Shen J, Liu X Q, Wang S M, et al. Palaeoclimatic changes in the Qinghai Lake area during the last 18000 years. Quat Int, 2005, 136: 131-140

13 Wang R L, Scarpitta S C, Zhang S C, et al. Later Pleistocene/Holocene climate conditions of Qinghai-Xizhang Plateau (Tibet) based on carbon and oxygen stable isotopes of Zabuye Lake sediments. Earth Planet Sci Lett, 2002, 203: 461-477

14 Zhu L P, Wu Y H, Wang J B, et al. Environmental changes reflected from the core sediments since $8.4 \mathrm{ka}$ in Nam Co, central Tibet of China. Holocene, 2008, 18: 831-839

15 Ju J T, Zhu L P, Wang J B , et al. Water and sediment chemistry of Lake Pumayum Co, South Tibet, China: Implications for interpreting sediment carbonate. J Paleolimn, 2010, 43: 463-474

16 Herzschuh U, Birks H J B. Evaluating the indicator value of Tibetan pollen taxa for modern vegetation and climate. Rev Palaeobot Palynol, 2010, 160: 197-208

17 Wang J B, Zhu L P, Nishimura M, et al. Spatial variability and correlation of environmental proxies during the past 18000 years among multiple cores from Lake Pumoyum Co, Tibet, China. J Paleolimn, 2009, 42: 303-315

18 Henderson A C G, Holmes J A. Palaeolimnological evidence for environmental change over the past millennium from Lake Qinghai sediments: A review and future research prospective. Quat Int, 2009, 194: 134-147

19 Shen J, Yuan H Z, Liu E F, et al. Spatial distribution and stratigraphic characteristics of surface sediments in Taihu Lake, China. Chin Sci Bull, 2011, 56: 179-187

20 Kastner S, Ohlendorf C, Haberzettl T, et al. Southern hemispheric westerlies control the spatial distribution of modern sediments in Laguna Potrok Aike, Argentina. J Paleolimn, 2010, 44: 887-902

21 Tenzer G, Meyers P, Knoop P. Sources and distribution of organic and carbonate carbon in surface sediments of Pyramid Lake, Nevada.
J Sediment Res, 1997, 67: 884

22 Vogel H, Wessels M, Albrecht C, et al. Spatial variability of recent sedimentation in Lake Ohrid (Albania/Macedonia). Biogeosciences, 2010, 7: 3333-3342

23 Wang J B, Zhu L P, Wang Y, et al. Comparisons between the chemical compositions of lake water, inflowing river water, and lake sediment in Nam Co, central Tibetan Plateau, China and their controlling mechanisms. J Great Lake Res, 2010, 36: 587-595

24 Kang S C, Yang Y P, Zhu L P, et al. Modern Environmental Processes and Changes in the Nam Co Basin, Tibetan Plateau (in Chinese). Beijing: China Meteorological Press, 2011. 296-299

25 Wang D. The geography of aquatic vascular plants of Qinghai-Xizang (Tibet) Plateau (in Chinese). Dissertation for the Doctoral Degree. Wuhan: Wuhan University, 2003. 74-85

26 Li Z Q, Zhang M, Xu J. Biodiversity and community ecology of aquatic plant in lake Nam Co, Tibetan Plateau (in Chinese). Acta Hydrobiol Sin, 2011, 35: 1-10

27 Guan Z H, Chen C Y, Ou Y X, et al. Rivers and Lakes of Xizang Contents (in Chinese). Beijing: Science Press, 1984. 176-182

28 Zhu L P, Xie M P, Wu Y H. Quantitative analysis of lake area variations and the influence factors from 1971 to 2004 in the Nam Co basin of the Tibetan Plateau. Chin Sci Bull, 2010, 55: 1294-1303

29 Wang J B, Zhu L P, Wang Y, et al. Spatial variability of recent sedimentation rate and variations in the past 60 years in Nam Co, Tibetan Palteau, China (in Chinese). Quat Sci, 2011, 31: 535-543

30 Wang J B, Zhu L P, Wang Y, et al. A comparison of different methods for determining the organic and inorganic carbon content of lake sediment from two lakes on the Tibetan Plateau. Quat Int, 2012, 250: 49-54

31 Lami A, Turner S, Musazzi S, et al. Sedimentary evidence for recent increases in production in Tibetan Plateau lakes. Hydrobiologia, 2010 648: $175-187$

32 Meyers P A, Ishiwatari R. Lacustrine organic geochemistry-An overview of indicators of organic matter sources and diagenesis in lake sediments. Org Geochem, 1993, 20: 867-900

33 Herzschuh U, Mischke S, Meyer $\mathrm{H}$, et al. Lake nutrient variability inferred from elemental $(\mathrm{C}, \mathrm{N}, \mathrm{S})$ and isotopic $\left(\delta^{13} \mathrm{C}, \delta^{15} \mathrm{~N}\right)$ analyses of aquatic plant macrofossils. Quat Sci Rev, 2010, 29: 2161-2172

34 Krishnamurthy R V, Bhattacharya S K, Kusumgar S. Palaeoclimatic changes deduced from ${ }^{13} \mathrm{C} /{ }^{12} \mathrm{C}$ and $\mathrm{C} / \mathrm{N}$ ratios of Karewa lake sediments, India. Nature, 1986, 323: 150-152

35 Meyers P A. Applications of organic geochemistry to paleolimnological reconstructions: A summary of examples from the Laurentian Great Lakes. Org Geochem, 2003, 34: 261-289

36 Woszczyk M, Bechtel A, Gratzer R, et al. Composition and origin of organic matter in surface sediments of Lake Sarbsko: A highly eutrophic and shallow coastal lake (northern Poland). Org Geochem, 2011, 42: 1025-1038

37 Eglinton G, Hamilton R J. Leaf epicuticular waxes. Science, 1967, 156: $1322-1335$

38 Cranwell P A. Chain-length distribution of $n$-alkanes from lake sediments in relation to post-glacial environmental change. Freshwater Biol, 1973, 3: 259-265

39 Cranwell P A. Lipid geochemistry of sediments from Upton Broad, a small productive lake. Org Geochem, 1984, 7: 25-37

40 Ficken K J, Li B, Swain D L, et al. An $n$-alkane proxy for the sedimentary input of submerged/floating freshwater aquatic macrophytes. Org Geochem, 2000, 31: 745-749

41 Mead R, Xu Y P, Chong J, et al. Sediment and soil organic matter source assessment as revealed by the molecular distribution and carbon isotopic composition of $n$-alkanes. Org Geochem, 2005, 36: 363-370

42 Giger W, Schaffner C, Wakeham S G. Aliphatic and olefinic hydrocarbons in recent sediments of Greifensee, Switzerland. Geochim Cosmochim Acta, 1980, 44: 119-129

43 Cranwell P A, Eglinton G, Robinson N. Lipids of aquatic organisms as potential contributors to lacustrine sediments-II. Org Geochem, 1987, 11: 513-527

44 Lin X, Zhu L P, Wang J B, et al. Sources and spatial distribution character of $n$-alkanes in surface sediments of Nam Co on the Tibetan 
Plateau (in Chinese). J Lake Sci, 2009, 21: 654-662

45 Gilbert R. Spatially irregular sedimentation in a small, morphologically complex lake: Implications for paleoenvironmental studies. J Paleolimn, 2003, 29: 209-220

46 Hilton J, Lishman J P, Allen P V. The dominant processes of sediment distribution and focusing in a small, eutrophic, monomictic lake. Limnol Oceanogr, 1986, 31: 125-133

47 Murase J, Sakamoto M. Horizontal distribution of carbon and nitro- gen and their isotopic compositions in the surface sediment of Lake Biwa. Limnology, 2000, 1: 177-184

48 Sifeddine A, Meyers P A, Cordeiro R C, et al. Delivery and deposition of organic matter in surface sediments of Lagoa do Caçó (Brazil). J Paleolimn, 2011, 45: 385-396

49 Wang J B, Zhu L P, Daut G, et al. Bathymetric survey and modern limnological parameters of Nam Co, central Tibet (in Chinese). J Lake Sci, 2009, 21: 128-134

Open Access This article is distributed under the terms of the Creative Commons Attribution License which permits any use, distribution, and reproduction in any medium, provided the original author(s) and source are credited. 